\title{
A PECULIAR HEMATITE ORE ON THE TRACT OF THE DURHAM MINE, DURHAM, PENNA. ${ }^{1}$
}

\author{
W. S. BAYLEY.
}

The Durham iron mine is situated in Bucks County, Penna., about I I $/ 2$ miles south of Easton and from $1 / 2$ to I mile west of the Delaware River. It is one of the oldest mines in the United States and was formerly one of the most important. It was first opened in 1698 , and in 1727 it furnished ore to a furnace built near the village of Durham. During the War of the Revolution, this furnace supplied much of the shot and shell used by the Continental Army.

The ore deposits are in a ridge of pre-Cambrian gneisses, which is the western extension of Musconetcong mountain in New Jersey. The geological conditions over most of the ridge are similar to those in the Highlands of New Jersey, described elsewhere. The prevailing gneiss is a phase in which potash is the predominant alkali—called the Byram gneiss in the folios of the U. S. Geological Survey. In addition, there are present layers of a soda-rich gneiss-the Losee gneiss of the U. S. Geological Survey-and others of a basic gneiss rich in iron and magnesium, known as the Pochuck gneiss. These layers are very flat lenses. The gneisses all possess an elongate or pencil structure, the pitch of which is the same as the pitch of the lenses. Moreover, many of the gneisses are schistose, in which case the dips and strikes of the structure and of the lenses are parallel. The rocks are believed to be igneous except perhaps a few of the basic gneisses which may be metamorphosed sediments, possibly limestones.

The ore bodies that have been worked by the Durham mine

\footnotetext{
${ }^{1}$ Read before the Geological Society of America, Washington meeting, I9I I,
} and published with the permission of the Director of the U. S. Geol. Survey. 
are divisible into two groups, one on the northeast peak of the ridge, known as Rattlesnake Hill, and the other on its southwest peak, known as Mine Hill.

The Rattlesnake Hill deposits are like those occurring in the gneisses elsewhere in the Highlands. They are essentially lenses of magnetite. An analysis by P. W. Shimer of a sample from a 2,ooo-ton ore-pile gave:

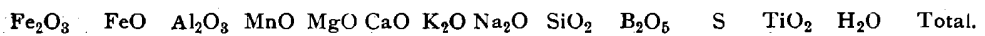

$\begin{array}{llllllllllllll}56.73 & \text { I I.50 } & 2.22 & \text {.IOO } & .82 & \text {.I6 } & .73 & .28 & 25.84 & .096 & \text {.105 } & .300 & \text { I.00 } & 99.886\end{array}$

This is essentially like the analyses of the New Jersey magnetites.

The Mine Hill deposits are of two kinds. In one the ore is magnetite and so far as can be determined from the descriptions that have been published, the ore bodies are similar in character to those in Rattlesnake Hill. A sample of "blue" ore from Mine Hill analysed by G. W. Maynard was probably magnetite. The analysis is quoted in line (I.) below. The other type is unique in the character of its ore. Its main mass is hematite, as will be seen by the analysis quoted in the second line below (II.), which was made by Professor Maynard on a sample of "red" ore from the underground workings at Mine Hill. The relation of

\begin{tabular}{|c|c|c|c|c|c|c|c|c|c|c|}
\hline & $\mathrm{e}_{2} \mathrm{O}_{3}$ & $\mathrm{FeO}$ & $\mathrm{Al}_{2} \mathrm{O}_{3}$ & $\mathrm{MgO}$ & $\mathrm{CuO}$ & $\mathrm{K}_{2} \mathrm{O} \quad \mathrm{Na}_{2} \mathrm{O}$ & $\mathrm{SiO}_{2}$ & $\mathrm{~B}_{2} \mathrm{O}_{5}$ & $\mathrm{~S}$ & Total. \\
\hline & 23.44 & 49.34 & $3.7 \mathrm{I}$ & I. 87 & $3 \mathrm{I}$ & tr. & 2I.OI & tr. & .13 & $99.8 \mathrm{I}$ \\
\hline & 67.57 & I. 53 & $.4 \mathrm{I}$ & $.2 \mathrm{I}$ & .59 & tr. & 29.27 & tr. & .24 & 99.82 \\
\hline
\end{tabular}

this ore to the magnetite (analysis I.) is not known, but it is evident that, as mined, it consisted mainly of hematite and quartz, since there were present in it 96.84 per cent. of $\mathrm{Fe}_{2} \mathrm{O}_{3}$ and $\mathrm{SiO}_{2}$ to 2.98 per cent. of all other components. In this respect it is different from all the other iron ores in the gneisses of the Highlands.

Hematite ores, it is true, occur in widely scattered areas through the Highlands but they are associated with pre-Cambrian sedimentary rocks and not with the gneisses. So far as can now be learned from the exposures they are bedded deposits, in which the ore is present to a large extent in the interstices between the grains of quartzites or conglomerates. 
In the western Adirondacks (St. Lawrence and Jefferson counties), however, hematite ores have been described by Smyth and others ${ }^{1}$ as existing in limestone and schists as lenticular bodies, composed of an amorphous, red, powdery mass of hematite containing lumps and concretions of hard specular ore. Sometimes the ore has a mammilary structure and occasionally the speculàr ore is micaceous. ${ }^{2}$ These ores are regarded as being formed by the replacement of limestone through the agency of ferriferous waters that obtained their iron from decomposing pyrite in neighboring granites and schists. ${ }^{3}$

Another type of hematite deposit in the Adirondacks is illusstrated by the Mt. Defiance Mine just south of Fort Ticonderoga, where the ore is a massive hematite filling a vertical fissure in gneiss. Mixed with the ore there is a considerable quantity of quartz and calcite. This deposit is ascribed to the circulation of underground water. ${ }^{4}$

It is impossible to learn now whether the ore that was called "red ore" by Professor Maynard was like any of the types of hematite occurring in the Adirondacks or not. On the surface at Mine Hill, however, there are openings that expose a hematite ore that is quite different from any ore that has been described heretofore from the Highlands or the Adirondacks. In most places this is a mixture of hematite and milky quartz that looks uncommonly like vein quartz. The hematite is scattered uniformly through the quartz as little grains up to 3 millimeters in diameter, exhibiting now and then a distinct crystal face, which often is marked by striations that suggest polysynthetic twinning. Nothing else is seen in the hand specimen nor in the thin section except an occasional smear of limonite. The quartz is granulated. Larger fragments with ragged contours are embedded in a fine-grained mosaic of quartz grains that appear to be inter-

${ }^{1}$ Bull. N. Y. State Museum, No. I2I, I908, p. 7 I-72 and 47th Ann. Rep.

N. Y. State Museum, I894, p. 692.

${ }^{2}$ Ioth Census Report, Vol. XV., I885, p. I4I.

${ }^{3}$ 6oth Rep. N. Y. State Museum, I907, p. 19-20.

‘6oth Rep. N. Y. State Museum, I907, p. I7. 
crystallized. The larger grains are crossed by strain shadows, but the small ones forming the mosaic are entirely free from all forms of optical distortion. Here and there the mosaic penetrates the larger grains as little veins. It is not probable that material of this kind was ever used as ore because of the great difficulty of separating the hematite from the quartz, and yet it is evident from the size of the holes left on the surface of the hill that considerable ore must have been obtained from some of the pits. An analysis by Dr. Shimer of a sample from 4,000 tons of ore obtained from the surface mine, which probably includes not only some material obtained from these pits, but also material from underground workings in the same or similar deposits, gave :

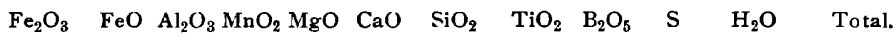

$\begin{array}{llllllllllll}61.07 & 5.66 & .96 & \text {.10 } & \text {.I7 } & .07 & 30.45 & .103 & .06 & .127 & \text { I.I5 } & 99.92\end{array}$

This is essentially a mixture of hematite, magnetite, limonite and quartz. Assuming that all the water present is in limonite the percentage proportions of the three constituents are: Limonite, 7.85 ; magnetite, I8. Io; hematite, 42.24 and quartz 30.45 . It is evident that the ore mined was much richer in hematite than that now exposed. That which was obtained from the surface probably occupied the holes now appearing as pits. Whether it occurred as lenses like the magnetite, cannot be stated. The quartz hematite aggregate that is now exposed constitutes a quarry wall that looks not unlike the face of a joint plane. Its general appearance suggests a huge vein mass, but since the contacts of the mass with the neighboring rocks cannot be seen its relations to these can only be surmised.

Other phases of what is believed to be the same geological mass have been found in several test pits that have been dug on the south slope of the hill on the side of the road from Monroe to Durham. These test pits are about $1 / 3$ mile southwest of the open pits or quarries on the hill - the country between the two being covered. The ore in their dump heaps is a medium grained, gray and white rock, in some cases massive, in others slightly schistose, 
and in others porous and drusy. Little irregular cavities occur here and there through the rock and from their walls project little crystals of quartz and hematite. These cavities suggest very strongly the "caves" or "pockets" in the gem-bearing pegmatites of Maine. ${ }^{1}$ The ore is an aggregate of little grains and crystals of hematite in a white material which in some specimens is granulated milky quartz and in others is a mixture of milky quartz and a very fine-grained mass of a soft white barite. In some specimens the material is almost exclusively barite, the quartz being restricted to a few small glassy grains scattered through the finely granular white barite mass.

In the specimens characterized by a white schistose groundmass the quartz is all mosaic. Tiny veins of limonite cut through it and scattered through it are small irregular masses of the same mineral. In those specimens in which barite is an important component the sulphate occurs, mainly, as envelopes of small grains surrounding the hematite and the remains of corroded quartz grains. These latter have extremely irregular outlines and often show strain shadows.

I am indebted to Dr. D. F. McFarland, of the Chemical Department of the University of Illinois, for the analysis of a specimen of the ore containing barite. In this there were 4.77 per cent. quartz, 8I.74 per cent. $\mathrm{Fe}_{2} \mathrm{O}_{3}$ and $\mathrm{I}_{3}$.8o per cent. $\mathrm{BaSO}_{4}$.

The occurrence of barite in the pre-Cambrian iron ores of the Highlands region has never heretofore been reported. It has been found in association with hematite in the Parish ore bed near Fowler, N. Y., and near the village of Little York, 6 or 7 miles east of Gouverneur, in the same State. In the Parish mine, however, it occurs in little geodes in specular ore, and at Little York in a vein composed of barite, hematite, sphalerite, chalcopyrite, and calcite. Mr. Newland, to whom I am indebted for the information, writes that even at Little York the barite is uncommon.

${ }^{1}$ E. S. Bastin, "Geology of the Pegmatites and Associated Rocks of Maine," U. S. Geological Survey, Bulletin No. 445, Washington, I9I I, p. 26-27, 82, 84,86 . 
It is clear that the Durham occurrence is unique. It would be extremely interesting to know something of its relations to the vein-like mass of quartz and hematite in the quarry walls, and to the country rocks. The only suggestion concerning its origin that occurs to the writer is that the quartz-hematite mass is in the nature of a pegmatitic quartz vein and that the barite is a later introduction into the pore spaces of the original rock and along fracture cracks between the grains of its quartz mosaic and the larger quartz grains and hematite crystals. Whatever the origin of the ore, it is probable that it was not the same as that of the hematite in the pre-Cambrian sediments. The barite may have come from Newark beds, the northern contact of which, with the gneisses, is now at a fault about a mile south of the mine. 